\title{
Magic Realism in the Novels of Amitav Ghosh and Zulfikar Ghose
}

\author{
Md Samiul Azim
}

Assistant Professor, Netaji Subhas Mahavidyalaya, Haldibari, Cooch Behar, West Bengal, India

\begin{abstract}
Magic realism, of late, has become the vehicle of expression for some writers for their narratives, After Marquez who hails from South America, in Indian subcontinent Amitav Ghosh and Zulfikar Ghose have tried their hands in magic realism. Since the 1980s, the words "magic realism" and "magical realism" have been widely used and studied by critics and academics. The words are a pair of oxymoron, a word used to describe the forced connection between two discordant concepts. In recent years, magical realism has gained popularity. Because it follows the addition of conflicting components, it has become a popular form of narrative. Both Ghosh and Ghose are author of trilogy and have utilised magic realism with dexterity in some of their novels.
\end{abstract}

Keywords - Magic realism, Oxymoron, Marquez, Discordant, Trilogy

\section{INTRODUCTION}

'Magical realism' is a term used to describe a type of reality. Franz Roh, a German art critic, invented the phrase "magic realism" in 1977.In 1925, he coined the phrase to describe a new type of post-expressionist painting that he saw emerge in the Republic of Weimar. Although the word was originally and mostly linked with painting, it has now expanded to encompass a wide range of disciplines. The majority of magical realism cultural development has occurred in fiction since the term's introduction in 1925 . Although there is no consensus on the term's origin, some art historians believe it dates back to the Middle Ages. As a result of postcolonial technique, this narrative style allows us to view and debate reality in a new way- a different way of looking at reality from the Western way of looking at things. The words magic/magical realism come from the German 'Magischer Realismus,' which was rendered into Dutch'magisch realisme,' English 'magic realism,' and finally Spanish 'realismo magico'

Friedrich Freiherr Von Hardenberg, also known as Novalis, was a German author who wrote under the pen name .He was a romantic poet and philosopher from Germany. He was the first to put the idea into practise. Despite the fact that magical realism is most closely linked with Latin America the problem is that there are no geographical restrictions on where it can be discovered, nor are there any restrictions on how it may be found. It has limitations in terms of what it can be used for.The supernatural is not a simple or obvious matter, but it is an ordinary matter, and everyday occurrence-admitted, accepted, and integrated into the rationality and materiality of literary fiction. Magical realism is a narrative mode of fiction in which magical and realistic elements coexist with equal ontological status and also presents magical and realistic happenings where "the supernatural is not a simple or obvious matter, but it is an ordinary matter, and everyday occurrence-admitted, accepted, and integrated into the rationality and material realistic" (Zamora 3). By combining two perspectives, magical realism creates a new one.According to A $\mathrm{M}$ Bowers

"Much of the confusion concerning magic realism arises from the fact that it was contemporary with surrealism. Surrealist manifestos were written in 1924 and 1930 , and some claim it is a branch of this art movement. There are similarities between the two movements, and it is important to note that at a later date magic(al) realist writers, particularly Alejo Carpentier, were influenced by both Roh and the surrealists. The similarities are significant, not least the surrealists'desire to draw out the hidden psychic aspects of life into art, theirdesire for newness following war, and their attempts to harmonize contradictions and paradoxes"'(Bowers 24).

The magical and the realism are opposing elements of the oxymoron. The narrative style blurs the distinction between the supernatural and the mundane realist. Midnight's Children is regarded as a forerunner of renaissance in Indian English writing. Playing with language and syntax, focusing on history, liveliness of language, magic realism, and allegory are all elements of postmodernism. Bower says "All magic(al) realist writers have their own influences, some from contemporary writers, some stretching back to the origins of the term and some from before the term was coined. Whatever the influences, it is rare for a writer to be concerned with questions such as the origin of the critical term (Bower 40).Midnight's Children opens up a new universe of Indian English literature: 
"Although the Indian English novel emerged into a recognizable form in the 1930s after its false starts and gestation during more than six decades, it gained a striking momentum and magnitude only after the publication of Salman Rushdie's Midnight's Children in 1981. Rushdie's unprecedented use of Indian material in sprightly, ingenious and cleverly crafted and engaging narrative transactions gave a phenomenal head start to English-language fiction from the subcontinent . . . By the time Midnight's Children appeared, the language had already shed its alienness and 'exoticity'. Its local variant was getting enriched by inputs from the media, the advertisement and entertainment industry, rhetoric of political speech and diverse ranges of registers and reverberations. Propelled by the new receptivity and social dynamics, Midnight's Children brought linguistic innovations in the Indian English novel at the tipping point". (Volna et al 9-13)

Bower opines" The situation is similar for Salman Rushdie and his equally cosmopolitan compatriot Amitav Ghosh. Rushdie's writing is considered both British and Indian, as Ghosh's is considered both American and Indian. But,unlike Ondaatje's magical realism, the magical realist happenings in Rushdie and Ghosh's fiction occur in India, Pakistan, Britain and America.(Bower 50-51) Ghosh began writing his first magical realism novel, The Circle of Reason, while teaching at Delhi University. It was released in 1986. This work, in which Rushdie's influence may be seen, notably in his magical realism style,explores new ground in the corpus of Indian English-language writing.4 Ghosh was the winner of the Prix.According to Bower "In Indian writing, for instance, Salman Rushdie, Amitav Ghosh and Arundhati Roy are very notable prize winning writers and all are writers of magical realism, but they do not constitute a movement or group in Indian literature, eachbeing unconnected to the other and located in different countries. Rushdielives between England, India and New York. Ghosh lives between the United States and India, and Roy remains in India. Thus, Rushdie and Ghosh tend to be considered as diasporic Indian writers whose writing is influenced by their hybrid cultural context"(Bower 46)

In 1990, he received the Medicis Estranger Award for his debut novel, The Circle of Reason. Ghosh tries out new things in his science fiction novel The Calcutta Chromosome 1996.Here he uses an postmodernist storytelling style. Ghosh aspires to create a new epistemology outside of Western discourse. The anti-scientists want to develop a system for interpersonal communication. "Interpersonal transference", is a concept that goes beyond the western concept of separate persons.
In her review of Dancing in Cambodia, At Large in Burma for India Star, Meenakshi Mukherjee observes: "We have now come to expect each new Amitav Ghosh book to be different from what has appeared before. The wistful evocation of memory to reflect on divisions of land and people in The Shadow Lines (1988) had nothing in common with the disjointed magic realism of his apprentice novel, The Circle of Reason (1986). Neither, however, prepared any reader for the febrile frenzy of The Calcutta Chromosome (1995) where the history of malaria research is spiced with this story of subaltern subversions of Western science. The conflation of genres in ['Dancing in Cambodia'] is quite unlike what was tried by Ghosh's other non-fiction work, In An Antique Land (1992). In 'Dancing in Cambodia', travel, history, cultural commentary political reportage shade into one another, the whole permeated with ruminations on freedom, power, violence and pain. Other histories and other geographies come alive and align with our own through Ghosh's translucent prose". (Hawley 4)

Ghosh has moved away from Rushdie's "imaginative serious comic storytelling" and the incoherent magic realism in his first book. In The Shadow Lines, he has developed a flexible and complex mnemonic narrative. He ties the pieces of history together by Memory evocations that have commented on communal issues. The Indian subcontinent is tense. Like various forms of modern Indian English,

Amitav Ghosh has deftly adapted his style of overflowing with ideas from other authors, bringing together fragments of stories, historical events, time, and a variety of narratives voices. His books aren't about a certain location, area, or country. However, they are a brilliant kaleidoscope that plays a vital role in bringing the narrative elements to the emotional heart of the storey. His ability to tell stories comes into play when he's on stage. Separate and non-sequential representations of time and location have been merged to form the major narrative. The story's repeated changes from one point to another constitute a counterpoint to hegemonic history. This is a fundamental element in his works for revealing precise information. People' difficulties and sorrows influence of western culture. The novel also explores the relation between culture and imperialism. Alu is a weaver who leaves home to travel across the Indian Ocean to the oil town of Al-Ghazira on the Persian Gulf. The novel can be seen as an allegory about The Circle of Reason (1986), Amitav Ghosh's debut novel, follows the experiences of Alu, an eight-year-old orphan who lives in Lalpukur, West Bengal. It shows how traditional rural life is being destroyed by contemporary materialism Anthony Burgess argues that: "It juxtaposes stable traditional culture with a 
Diasporic, post-colonial culture, is a reading made within the paradigm of classical ethnography. For Amitav Ghosh, even societies that appear to be static and traditional are always diasporic". (Khair 13)

Amitav Ghosh is regarded as a master craftsman in the field of fiction for The Circle of Reason. It was regarded as a departure from the usual manner of English fiction writing. The novel has been translated into several European languages and has won numerous awards. The French version received the coveted Prix Medici Estranger literary prize. Ghosh in this work, introduces strange and odd events that are repeated and explored. They become an integral part of the story. The usage of metaphors and motifs has been employed, with the trip motif being the most common. Theme of Ghosh's works have elements of drama, mystery, and suspense .The books of Amitav Ghosh reflect the historicity of history. The Circle of Reason is a very well-crafted piece of fiction. Ghosh has effectively explored new possibilities for the Indian novel in this work. In the English language According to John C. Hawley:

"This first of Ghosh's novels is a complex tapestry of individualswhose lives overlap, pull apart, and separate and sometimes find each other again in new contexts. It is a story of obsession - obsessive rationalism that some embrace as science and others ridicule as insanity (the science of "queues" and purification by carbolic acid), and obsessive manhunts. The book is an early example of this novelist's tendency to push against the limits of a particular genre: after all, The Circle of Reason is, at once, a detective story, a story of exile, a travelogue, a women's rights tract, a Marxist protest, a plea for humanistic camaraderie, etc. The narrative techniques employed here sometimes share the characteristics of magical realism (Toru-debi, for example, strangely looks upon her Singer sewing machine as her child), but they are more generally straightforward and realistic. He does tend, though, to juggle a lot of characters, time zones, and localesin the telling of his tale". (Hawley 53-54)

He has created a name for himself in the literary world as a creative fiction crafter who has received widespread critical praise. Even in his debut work, The Circle of Reason, he had a strong sense of uniqueness (1986),It earned a lot of praise for its content experimentation and form. In fact, with the potential exceptions of The Shadow Lines and The Calcutta Chromosome, Ghosh has been obsessed by oceans and tidal zones in nearly all of his works to date. Ghosh's characters come from a diverse range of ethnic backgrounds. Sea, coastal areas, ranging from the Arabian Sea to the Bay of Bengal and the Persian Gulf (in The Persian Gulf).The Strait of Malacca (in The Circle of
Reason and In an Antique Land), to the Strait of Malacca (in The Circle of Reason and In an Antique Land).The Sundarbans delta and the Glass Palace (The Hungry Tide). Maybe one of the Ghosh's fascination with aquatic scenes in his works stems from the fact that these need flexible borders; "shadow lines" that Ghosh fervently contests. Accoding to Bower : "Amitav Ghosh shares a similar insider/outsider position although his form of magical realism is less exuberant, and less ubiquitous than that of Rushdie. There are two sources of magical realism in Ghosh's The Calcutta Chromosome ([1995] 1997). The first source verges on science fiction, as Ghosh's novel includes extremely advanced computer technology which allows the computer to have its own personality and the ability to seek out globally the smallest fact in seconds. The second source is more mystical, and follows the story of a religious sect who are endowed with the capacity for metempsychosis in that they are able to transfer their souls from one body to another across generations"( Bower 65)

On the other hand, Zulfikar Ghose writes on the disempowered indigenous peoples of South America's interiors, whose cultural beliefs and practises are always under assault, using magical realism as a postcolonial style of narrative. As expressed by Marquez, there is turmoil, bloodshed, and uncertainty.Zulfikar Ghose talks about carnage whether it comes to Colombian politics or Latin America in general. With the Partition's turmoil, the horrifying history and contemporary uncertainties lend themselves to the fantastic. For its ability to bring forth the "unearthy tidings" of a difficult past and wistful present, realism is favoured. Unlike Salman Rushdie, who utilises magic realism to "exercise his predilection for non-naturalism without abandoning the types of political and cultural involvement that are typically associated with social realism" (Warnes 99), Zulfikar Ghose deconstructs the human/inhuman binary in a subtle way. The 'civilised' Westerners pushed their way into the novel The Triple Mirror of the Self and bulldozed their way into the interiors of Xurupa, a tribal settlement to exhibit a blatant show of greed

Zulfikar Ghose's magical realist events take place in Latin America, unlike Amitav Ghosh's. Ondaatje's are found in Sri Lanka, whereas Rushdie's and Ghosh's are found in India, Pakistan, the United Kingdom, and the United States. The shock of the new is a source of magical realism, as shown in Zulfikar Ghose's books. The Unknown South America, eerie interiors, magnificently exotic locations, and a continuous surprising circumstances involving large hotel structures and technology developments It appears to be strange to be in the middle of a vast desert. The foundation of 
magical realism fiction is the reader's faith in and acceptance of the many kinds of fictitious reality that are presented to them (Bowers 40).

Ghose writes about locations and circumstances that the general public is unfamiliar with. In his search for identity, he appears to be avoiding reality. He, like Marquez and Guntur, occasionally abandons magical realism to speak realistically about the tragedies and violence of partition. His magical realism appears to emanate from the terrible reality of Partition and the Holocaust. Ghose was uprooted as a youngster as a result of really horrible violence and the resulting uprooting he witnessed. The novel's final section, The Triple Mirror of the Self Ghose, is written in a realistic style. It speaks about growing up in pre-independence Bombay and the historical reality of his youth. In the words of Fredric Jameson postmodernism is an "attempt to think the present historically in an age that has forgotten how to think historically in the first place" (3). However, magical realists employ historical allusions and historical revisions in their writings, making it possible to determine the link between magical realism and postmodernism.

The Figure of Enchantment, a rewrite of Shakespeare's The Tempest, is Ghose's famous novel. Here the significance of history and memory in the current day lives of the characters is wonderfully articulated. Gamboa, who has lived on the island of Santa Barbara for many years, has practically no recollection of what happened for he's lost both his daughter and his wife. His present reality is not less than a fantastic existence in which "a dead man ... dead now, alive still, the father and the daughter too dead, though each morning revived their breath, the voice persisted, the mind's phantoms strolled solidly on the beach, the warm breath of the voice came and went like the tide. Another's past is your past, the other that you now are is not of the self you formerly had but of some other" (Ghose, Figures 118).

Whether the boundaries are ontological, political, geographic, or general, "magical realism is a style suited to investigating and transgressing them" (Zamora 5). Don Bueno, a novel by Zulfikar Ghose, takes the reader on a journey throughout the globe. Diversity of South American landscapes, from the interior's humid and dark forests to the coast's lush greenery, the crystalline heights of the Andes, as well as the Atlantic and Pacific seacoasts all has featured in his novels. A weaver of enchantments, Zulfikar Ghose's spells in Don Bueno connect with complex symbolism despite their deceptive simplicity. Despite the surreal scenes, he does not lose touch with reality. With the passage of time, the father's abandoned kid Don Bueno, who grew up to become a terrorist known as Simon Bolivar who arrived at Santa Rosa for the second time.

He had a quarrel with a stranger while visiting a pub, and ended up killing the stranger, who turned out to be his father, and thus the cycle of inescapable fates was completed. Ghose in a transparent and implausible manner (which is part of the novel's magic or super realism)combines "realistic conventions with mystical aspects... not done for the purpose of it, but to get that symptomatic ghostly sheen that must be seen as an effort to communicate what is being spoken" (Maillard 12).

A reader freely watches the results of events rather than seeking reasons in Ghose's works such as $A$ New History of Torments. The writer does not give a causal explanation for the strange turn of events, unanticipated twists and turns in the lives of characters who become uprooted and alienated. Neither the author nor the reader is looking for a rational analysis; instead, they are watching them go through the ordeal. Alienation's agony Ghose brings together the affluent and the poor in this storey, like he did in The Incredible Brazilian.

In several Latin American countries, scenic elements are combined with fairy tale narrative to create a bleak, dreamy realm and landscape. The narrative and ideas are intertwined in a fascinating way to create a stunning form - magic realistic happenings. Jorge Rojas Jimenez, a ranch owner, abandons his wife after 22 years for a lover, Margarita Aparicio, whom he planned to bring to his vast estate.

Ghose's writings include A New History of Torments, The Figures of Enchantment, and Don Bueno. Zulfikar Ghose's last book, A Triple Mirror of the Self, tries to clarify the ambiguous, nostalgia and bereavement, as well as pains of origins, memories, and identity .The usage of a series of symbols allows one to express oneself. Ghose uses magical events and rituals to emphasise reality's deceptive nature. Urim is a character in the novel who travels the world in search of the conclusion of his journey. He sees the mirror reflection of his journey's commencement and exists where he began. In his search for his origins, the hero journeys backwards across countries. Finally, he'll arrive at Bombay. In this section, the narrator, who now goes by the name Roshan, recalls his adolescent years in Bombay and eventually ends himself in the Andes foothills.

Zulfikar Ghose incorporates mythology, particularly the magical realistic narrative of Indian tribes in the interiors, in which a whole tribe became impotent and perished. When the men of the village used the power 
of magic to expel a spider known as the 'black widow,' the spider infected the whole town. The men of enemy tribe "transformed themselves into spiders and crawled into this land. And one night they crept up the legs of all the women of the tribe and wove an invisible and impenetrable web across their sex"(Ghose, Don 111).

Ghose provides a postcolonial viewpoint through the use of magic realism language and circumstances.: Captain Afonso says "You should know this about any human being, however primitive. He inherits a code of symbols whether he is born in the jungle out there or in London. For we all are creatures of unaccountable compulsions. ... Your uniformed soldier is no different from a painted warrior. Your primitive may eat his enemy's flesh and your civilized man will do the same thing, though only metaphorically, but neither will sleep with his sister" (Ghose, A New 175). In a society when having only one version of a tale is harmful, he emphasises the value of magic realism: "there could be no wisdom because there could be no relief from the body's pain; and the mind's bemusement with abstract thought was only a strategy to distract itself from an infinite despair" (Ghose, Figures 63).

\section{CONCLUSION}

So both Amitav Ghosh and Zulfikar Ghose have used magic realism in their respective novels with dexterity. Amitav Ghosh follows the magic realism technique employed by such Latin American writers as Gabriel Garcia Marquez in his narrative technique. Indeed, the novels Amitav Ghosh and Zulfikar Ghose have enriched the English literature and their novels are unique example of a postcolonial novels that combines elements of magical realism. Writers have deliberately resorted to magical realism to uncover the surreal and unreal dimensions of the Indian subcontinent and South American continent and thus their writings have become apostolic works.

Both Ghosh and Ghose's use of magical realism makes their novels more interesting and adds a fantastic element to their books. Imagination is deliberately used to transcend reality. Magical realism helps writers to speak unspoken. Various themes and elements of magical realism, such as themes of diversity, migration, immigration and separation, are used symbolically in various events of the text. Compassion and fear, space and time, sketches, eroticism and representation - all these make up the incomparable beauty of their novels. In this case, it is worth mentioning the use of poetic language. Both Amitav Ghosh and Zulfikar Ghosh use magical realism as an effective way to tackle the problem of postcolonialism. By linking and combining historical events, mythological and fictional stories, Amitav Ghosh and Zulfikar Ghosh seek to create and convey real pictures of post-colonial India and South America in one place.

\section{REFERENCES}

[1] Bowers, Maggie Ann. Magic(al) Realism. London and New York: Routledge, 2004.

[2] Ghosh, Amitav. The Circle of Reason. New York: Viking, 1986.

[3] The Shadow Lines. New Delhi: Oxford University Press, 1995.

[4] --. The Calcutta Chromosome. New York: Aron, 1996.

[5] ---. The Hungry Tide. London: Harper Collins, 2004

[6] --. In An Antique Land. New Delhi: Ravi Dayal Publisher, 1992.

[7] --. Dancing in Cambodia and at Large in Burma. New Delhi: Penguin Books, 2010.

[8] Ghose, Zulfikar. A New History of Torments. London: Black Swan, 1984.

[9] ---. Don Bueno. London: Hutchinson, 1983.

[10]---. Figures of Enchantment. New York: Harper and Row Publishers Inc., 1986.

[11]---. The Triple Mirror of the Self. London: Bloomsbury Publishing Ltd., 1994.

[12] Hawley, John C. "Amitav Ghosh: An Introduction". Contemporary Indian

[13] Writers in English. New Delhi: Foundation Books, 2005

[14] Khair, Tabish. (ed.) Amitav Ghosh: A Critical Companion. New Delhi: Permanent Black, 2003.

[15] Volna, Ludmila, Nilanshu Kumar Agarwal and Murari Prasad (eds.) Children of Midnight: Contemporary Indian Novel in English. New Delhi:

[16] Pencraft International, 2012.

[17]Warnes, Christopher. Magical Realism and Postcolonial Novel: Between Faith and Irreverence.New York: Palgrave Macmillan, 2009.

[18]Zamora, Lois and Wendy B. Faris. Magical Realism: Theory, History, Community, Durham, NC and London: Duke UP, 1995. 